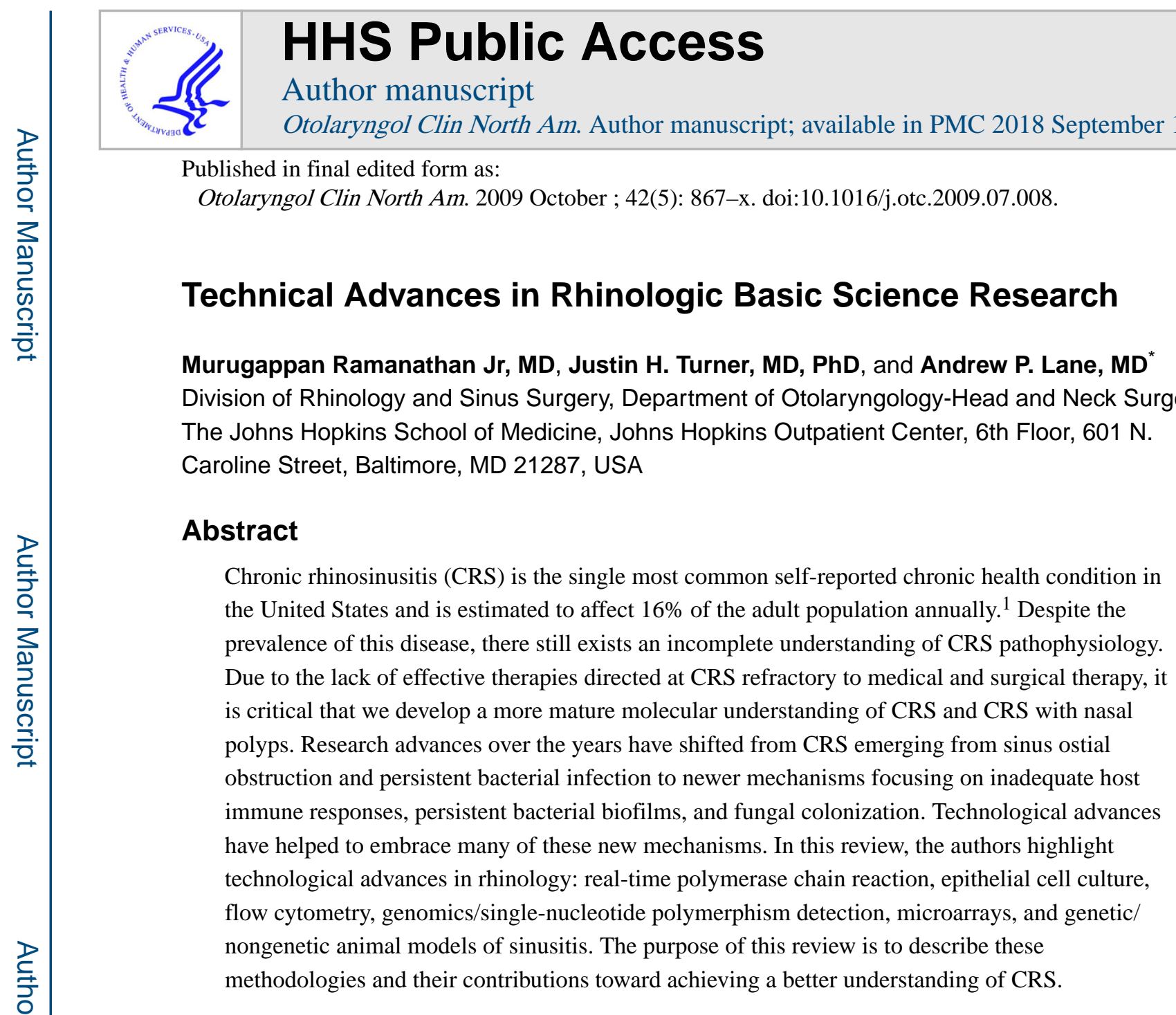

\title{
Keywords
}

Chronic rhinosinusitis; Flow cytometry; Real-time PCR; Sinonasal epithelial cells; Microarray; Polymorphisms; Animal models

\section{REAL-TIME PCR}

The polymerase chain reaction (PCR) has revolutionized molecular research over the past several decades. PCR is a method that allows exponential amplification of short DNA sequences within a longer double-stranded DNA(dsDNA) and requires the use of primers that are complementary to a defined sequence on each of the 2 strands of DNA. These primers are then extended by a heat stable DNA polymerase (Taq polymerase) to complete the sequence, leading to logarithmic amplification. Historically, PCR products were run on an agarose gel and stained with an ethidium bromide stain because the reaction was qualitative, determining the presence or absence of a product. Another variation of this technique is reverse transcriptase PCR (RT-PCR), which uses the enzyme reverse

Corresponding author. alane3@jhmi.edu (A.P. Lane). 
transcriptase to convert mRNA to cDNA for use in a PCR reaction. Real-time PCR was developed in efforts to quantitatively assess DNA copy number. ${ }^{2}$

\section{Real-Time PCR: the Technique}

Real-time PCR has the ability to monitor the progress of PCR as it occurs "in real time." In this technique, reactions are characterized by the point in time during cycling when amplification of a target is first detected, rather than the amount of target accumulated after a fixed number of cycles. The higher the starting copy number of the gene or nucleotide sequence, the sooner a significant increase in fluorescence is detected. In contrast, conventional PCR and RT-PCR measure the amount of accumulated PCR product at the end of the cycle.

Two primary fluorescence-based sequence detection systems are used: Taqman and SYBR Green chemistry. Taqman chemistry uses fluorogenic labeled probes to enable the detection of PCR product as it accumulates. In the Taqman system, specific hybridization between the probe and target is required to generate a fluorescent signal. Probes can also be labeled with different distinguishable reporter dyes, which can allow for amplification of 2 distinct sequences in 1 tube. The primary disadvantage of this system is that specific probes need to be designed for each reaction. SYBR Green dye is a highly specific dye that binds to all dsDNA. As amplicons are created during PCR, SYBR Green binds to all dsDNA causing an increase in fluorescence proportional to the amount of PCR product created (Fig. 1). The primary advantage of the SYBR Green system is that no probe is required, which reduces assay time. This system, however, may generate false-positive signals as SYBR Green dye will bind to any dsDNA.

Real-time PCR data are acquired by a computer and can be analyzed in various ways. Cycle thresholds $\left(\mathrm{C}_{\mathrm{T}}\right)$ reflect the fractional cycle number of a gene or sequence at which the fluorescence passes the fixed threshold, which is a sample that does not contain a template. The $\Delta \mathrm{C}_{\mathrm{T}}$ method uses the difference in $\mathrm{C}_{\mathrm{T}}$ value obtained between a normalizing housekeeping gene (18 S ribosomal RNA, GAPDH) and the target gene to calculate relative quantification $\left(\Delta \mathrm{C}_{\mathrm{T}}=\right.$ the difference in threshold cycles for target and housekeeping gene $){ }^{3}$

\section{Real-Time PCR Applications in Rhinology}

Although conventional PCR and RT-PCR have been used for decades in rhinologic research to evaluate for the qualitative presence of markers/genes in nasal tissue, quantitative realtime PCR has largely grown to replace this technique over the past 5 years. Claeys and colleagues $^{4,5}$ and Lane and colleagues initially demonstrated the expression of toll-like receptors (TLRs), human beta defensins, and costimulatory molecules from nasal epithelial cells using real-time PCR. Richer and colleagues ${ }^{6}$ demonstrated marked reductions in the level of expression of several genes involved in epithelial barrier maintenance and repair in the inflammatory state of CRS. Furthermore, numerous studies have shown altered sinonasal innate immune epithelial gene expression including TLRs, interleukin 22 (IL22), TLRs, and lactoferrin in patients with CRS compared with normal patients. ${ }^{7-9}$ Although this literature review is incomplete, it serves to demonstrate that real-time PCR is a powerful rapid method to screen for alterations in genes/markers between control populations and CRS. 


\section{IN VITRO CELL CULTURE SYSTEMS}

The hallmark of patient-oriented basic science research is studying the differences between diseased and nondiseased tissue samples. Harvesting sinonasal mucosal biopsies in the operating room is critical to better understanding the cellular and molecular differences in CRS. These tissue biopsies are primarily used either for immunohistochemical staining or to isolate mRNA for PCR. The limitations of these biopsies include small amounts of tissue and the inability to biologically manipulate mucosal cells. Currently, there are no immortalized nasal cell lines from either normal patients or those with CRS. There have been reports of establishing primary nasal fibroblast cultures and of groups using immortalized lower respiratory epithelial cell lines (A549 and BEAS-2B) given the similarities between the upper and lower airways. ${ }^{10-12}$

\section{Primary Sinonasal Epithelial Cells in Culture/Brushed Epithelial Cells}

A new advance in rhinologic research has been the use of primary sinonasal epithelial cells (SNECs) grown in culture at the air-liquid interface. This model involves extracting nasal epithelial cells from mucosal biopsies and growing them in cell culture (Fig. 2A) as previously described. ${ }^{5}$ After these cells reach confluence, they are split into transwell inserts with air above the insert and medium below (Fig. 3), mimicking the natural microenvironment of the nose. These cells eventually become ciliated, and histologically resemble fresh brushings of SNECs. Another novel technique to acquire sinonasal tissue is mucosal brush biopsy of the middle meatus, which can be performed in the clinic using topical anesthesia (Fig. 2B). The advantage of brushed epithelial cells is that they can be collected easily in the clinic with local anesthesia.

This technique also facilitates longitudinal evaluation of epithelial cell function in nonoperative patients. These brushings can be used in cell culture or can be used for PCR or primary analysis by immunohistochemistry or flow cytometry (see later discussion). SNECs can be stimulated/suppressed with exogenous cytokines and their effector function can be determined by analyzing the cells for gene/protein expression or the culture medium can be analyzed for secreted proteins.

\section{Recent Advances in Rhinology Research Using SNECs}

Numerous investigators have used SNECs from CRS patients in vitro to stimulate the production of cytokines and other effectors. Lalekar and colleagues ${ }^{13}$ demonstrated that SNECs can be stimulated with chitin to produce the Th2-associated molecule, acidic mammalian chitinase (AMCase), and eotaxin-3. This finding was the first to suggest the possible existence of an innate immune pathway for local defense against chitin-containing organisms in the sinonasal tract. It is possible that dysregulation of this function could precipitate or exacerbate Th2 inflammation, potentially acting as an underlying factor in CRSwNP. Using SNECs, Kim and colleagues ${ }^{14}$ showed that the nasal epithelial costimulatory molecules, B7-H1 and B7-DC, are inducible and elevated in CRS compared with controls. In addition, through using brushed nasal epithelial cells, Saatian and colleagues ${ }^{15}$ demonstrated that SNECs express B7-H2 and B7-H3 and may act as antigenpresenting cells to activated mucosal T cells. Clearly, the SNEC model, which mirrors the 
natural mucosal epithelium of the nose, holds great promise to study the effects of various pharmacologic and environmental stimuli.

\section{FLOW CYTOMETRY}

The technique of flow cytometry or fluorescence-activated cell sorting (FACS) has revolutionized single-cell protein analysis and sorting based on cellular protein markers, surface and intracellular. Traditionally, Western blots have been used to measure specific protein expression in cellular or mucosal lysates. The enzyme-linked immunesorbent assay (ELISA) is another technique to measure soluble secreted protein. Unless the tissue source is homogenous, like cell lines, Western blots or ELISA cannot determine which cell type is expressing or secreting a certain protein. Flow cytometry, however, has the powerful ability to sort individual cell populations based on multiple fluorescent markers specific for various receptors or proteins.

\section{Flow Cytometry: the Technique}

Flow cytometry uses the principles of light scattering, light excitation, and emission of fluorochrome molecules to generate data from particles and cells. Individual cells and particles are hydrodynamically focused in a sheath of saline before intercepting a focused laser light source. Cell samples are first stained with fluorochrome-conjugated monoclonal antibodies. These stained cells then intercept the light source and scatter light, and fluorochromes are excited to a higher energy state. This energy is then released as a photon of light with specific properties unique to different fluorochromes. Ultimately, flow cytometry measures fluorescence per cell or particle. The analyzed cells can be sorted and collected for further analysis or the data can be stored in the form of a computer file, which can be analyzed as a histogram or quadrant. ${ }^{16}$ Most commonly, flow cytometry data are depicted as a 4-quadrant grid with an $\mathrm{x}$ and $\mathrm{y}$ axis, depicting different fluorochromes (Fig. 4). Each cell is depicted as a dot on the plot and its position reflects the fluorochrome intensity. A sample dot plot is shown in Fig. 4; $60 \%$ of the cells in this brushed cell sample are epithelial cells expressing TLR9.

\section{Recent Rhinologic Advances Using Flow Cytometry}

Numerous studies have used flow cytometry to elucidate the pathogenesis of CRS. In 1996, Bernstein and colleagues ${ }^{17}$ analyzed different lymphocyte populations in nasal polyps from patients with CRS. This study found that nasal polyp lymphocyte subpopulations may be derived from the local mucosal immune system as well as from random migration of peripheral blood lymphocytes secondary to adhesion molecules and chemokines, which are known to be present in nasal polyps. Conley and colleagues used flow cytometry to measure superantigen-specific $\mathrm{T}$ cell receptor domains in the peripheral blood of patients with nasal polyps. This study revealed that 7/12 patients with nasal polyps had a local superantigen effect on T cells. ${ }^{18}$ Our group has used flow cytometry extensively to analyze SNECs in control patients and those with CRS with polyps and has shown decreased Toll-like receptor 9 (TLR9) and interleukin 22 receptor (IL22RA-1) levels associated with CRSwNP. ${ }^{9,19}$ 


\section{MUCOCILIARY CLEARANCE AND CILIARY BEAT FREQUENCY}

Ciliary dysfunction is another proposed mechanism for CRS. Respiratory cilia beat in a coordinated manner with a specific frequency and pattern. It is this coordinated beating that clears debris laden mucus toward the natural sinus ostia in a well-established pattern. ${ }^{20}$ Studies have shown that stressors such as exercise or infection can alter ciliary beat frequency $(\mathrm{CBF})$. Numerous studies have also shown a decrease in sinonasal mucociliary clearance in CRS patients. Possible reasons for impaired mucus transport include reduced basal CBF and impaired mechanical mucociliary coupling. ${ }^{21-24}$

\section{Measuring CBF}

$\mathrm{CBF}$ can be measured in vivo using the saccharin transit test or scintigraphy, however these techniques do not take into account regional variations of CBF within the nasal cavity. Also, these studies do not differentiate between the role played by ciliary activity and the overlying mucus blanket. A new advance in measuring CBF has been the advent of highspeed digital microscopy. ${ }^{25}$ Numerous groups have developed methods of using digital microscopy and acquisition software. In 2003, Sisson and colleagues ${ }^{26}$ developed a fully digital imaging system to quantify $\mathrm{CBF}$ accurately and more efficiently compared with analog techniques. Dimova and colleagues ${ }^{27}$ adapted a similar system to measure CBF in primary nasal epithelial cells with fast data acquisition and calculation. One area of controversy among in vitro measurements of $\mathrm{CBF}$ is the effect of temperature on ciliary function. Some groups take CBF measurements at room temperature, whereas others perform these studies at physiologic body temperature.

To control for the effects of temperature on CBF, Schipor and colleagues ${ }^{28}$ developed a novel system using differential interference contrast (DIC) microscopy and to measure CBF at physiologic body temperature. This technique involves placing nasal epithelial cell explants into a temperature-controlled glass perfusion chamber. Microscopic images are visualized using a water immersion objective with DIC optics. Images are then captured using a high-speed monochromatic digital video camera at 250 frames per second. Video images are then analyzed using video imaging processing software on areas of epithelium containing beating cilia, and the frequency is calculated.

\section{Recent Advances Using CBF Measurements}

Several investigators have found altered CBF dynamics in CRS patients. Chen and colleagues $^{29}$ analyzed CBF in nasal epithelial cells from controls and CRS patients before and after exogenous stimulation with adenosine triphosphate. This study found no differences in basal CBF in controls and CRS patients but found that CRS patients had a minimal increase in CBF after ATP stimulation, concluding that this patient cohort has decreased sinonasal ciliary adaptation to environmental stimuli. Furthermore, Erickson and colleagues $^{30}$ used the same method to quantify CBF to demonstrate that retinoic acid is beneficial in ciliary regeneration in stripped maxillary sinus mucosa from rabbits. This study found that $\mathrm{CBF}$ was increased in retinoic acid treated mucosa compared with controls. Use of this enhanced technology to measure CBF will allow for a better understanding of how various environmental stimuli affect mucociliary clearance in CRS patients. 


\section{SINGLE-NUCLEOTIDE POLYMORPHISM GENOTYPING}

It is likely that genetic factors play a role in the pathogenesis of CRS. With the advent of sequencing the human genome, numerous polymorphisms have been associated with chronic disease, including CRS. Polymorphisms are a natural evolutionary process by which multiple phenotypes of a given population are able to exist, resulting in biodiversity and adaptation. Viewed in strictly molecular terms, a polymorphism is an inherited genetic variant that occurs in at least $1 \%$ of the human population, excluding spontaneous mutations. Numerous types of polymorphisms exist including single-nucleotide polymorphisms (SNP), restriction fragment length polymorphism (RFLP), and copy number polymorphisms (CNP). ${ }^{31} \mathrm{An}$ SNP is a DNA sequence variation occurring when a single nucleotide in the genome differs amongst the population. An SNP may occur in the coding region of a gene, thereby altering the amino acid sequence, or it may occur in a noncoding region. Variations in the DNA sequence of a gene can affect susceptibility to disease and how humans respond to pathogens and the environment.

\section{Detecting SNPs: the Technique}

Classically, screening for SNPs has employed the use of restriction enzymes, resulting in RFLPs. To examine a population for SNPs, genomic DNA is extracted from either blood or epithelial cells from buccal swabs. Restriction enzymes are bacterial derived enzymes that recognize and cut specific sequences of host or foreign DNA. Most human genes contain dozens of restriction enzyme target sites that, when cleaved, will produce a specific group of DNA fragments of different sizes. This technique allows for single nucleotide changes to be easily detected and for decades has been used as a screening tool to identify diseaseassociated genetic changes and mutations. With the advent of DNA sequencing, the entire genetic code for a specific protein can now be identified and compared with others in a similar population. New mass spectrometric and DNA microarray technologies also allow for high-throughput analysis of thousands of different single-nucleotide polymorphisms. ${ }^{32}$

\section{Recent Advances: SNPs and CRS}

Over the past 3 years, numerous SNPs associated with inflammatory mediators have been examined in CRS patients (Table 1). Tewfik and colleagues ${ }^{33}$ examined SNPs in the Tolllike receptor 2 (TLR2) gene, which is an innate immune receptor for bacterial lipopolysaccharide, and found no association with an increased incidence in CRS. Similarly, there have also been unsuccessful associations with matrix metalloproteinase 2 and leukotrienes. ${ }^{34,35}$ There have been a few positive associations with SNPs and CRS progression. ${ }^{36-42}$ Bernstein and colleagues examined SNPs in proinflammatory and antiinflammatory cytokines in control and polypoid CRS patients and found an SNP, TNF-alpha 308 , in the promoter region which is associated with a 2 -fold increase in developing polypoid CRS. Also, de Alarcon and colleagues found an increased association with leukotriene C4 synthase (LTC4S) and chronic hyperplastic eosinophilic sinusitis. Endam and colleagues found that 3 SNPs of the interleukin 22 receptor (IL22RA-1) have great predisposition to CRS. Although these studies are of low power, they demonstrate a possible genetic basis for certain cases of severe CRS. 


\section{DNA MICROARRAYS/GENECHIP}

Advances in microtechnology and computer-enhanced laser optics have allowed for the construction of a high-resolution hybridization probe, known as the DNA microarray. The microarray is a carefully constructed set of gene probes to which cDNA copies of RNA expressed within a cell can be hybridized. Computer-enhanced laser detection allows for quantification of this hybridization. The microarray technology uses the knowledge of the sequenced genome and is an extremely comprehensive tool for examining the differential gene expression in various specimens with and without disease. ${ }^{43}$

\section{Microarrays: the Technique}

Currently, there are 2 primary methods that are used for microarrays: the GeneChip (Affymetrix Corp) and cDNA microarrays. The Affymetrix GeneChip contains oligo-DNA probes directly synthesized onto glass slides. There are various chips available for different species and subsets of genes, with as many as 47,000 genes. In the cDNA microarray method, cDNA clones are fixed on a glass slide by mechanical microspotting or with noncapillary pens. These arrays can be manufactured in the laboratory and tend to be more expensive and time consuming. In both techniques, RNA samples are allowed to hybridize to the array, and computerized technology detects which probes the target DNA of interest has hybridized with, generating a signal intensity that is quantified. ${ }^{44}$ Microarrays are an extremely powerful tool for gene function analysis. Although the functions for most genes on these microarrays are still unknown, some genes still show homology to others with known functions. Although expensive, this technique allows for collection of large amounts of gene expression data with a minimum number of experiments.

\section{Evaluation of Gene Expression in CRS Using Microarrays}

Over the past 5 years, 5 major articles have identified causative genes in CRS using gene chip microarrays (Table 2). These studies, however, analyzed various disease states within the spectrum of CRS. Anand and colleagues ${ }^{45}$ performed the first study in 2006, comparing gene expression using the Affymetrix U133A gene chip in chronic hyperplastic sinusitis and control patients and found 4 specific genes were overexpressed: IL-6, IL-12A, IL-13, and TNF-alpha. However, this study did not differentiate between subclasses of CRS. In 2008, Payne and colleagues ${ }^{46}$ performed a small study comparing the unique population of noneosinophilic CRSwNP $(n=2)$ and controls $(n=2)$ and found increased expression of IL-6, IL-8, and monocyte chemoattractive protein, and decreased expression of IL-4 and IL-13. Stankovic and colleagues ${ }^{47}$ have reported the largest gene chip microarray study thus far, examining 10 patients each with CRSwNP, aspirin sensitive triad asthma polyps, and no disease. This study demonstrated that the CRSwNP phenotype showed up-regulation of the c-met proto-oncogene and protein phosphatase 1 regulatory subunit and a down-regulation of prolactin-induced protein and zinc alpha2 glycoprotein. Amongst these targets, overexpression of c-Met has been previously implicated in nasal polyps. ${ }^{48} \mathrm{C}-\mathrm{Met}$ is a receptor for hepatocyte growth factor, which has been shown to attenuate Th2-associated eosinophilic inflammation. Although there is a great deal of variation in terms of gene expression amongst various investigators, these gene chip microarray studies have uncovered new targets for further investigation. ${ }^{49,50}$ 


\section{ANIMAL MODELS OF SINONASAL DISEASES}

Animal models have allowed scientific investigators to explore human disease processes in ways that could not be safely or ethically performed in human subjects, or that would otherwise be too complex to complete. The increased use of animal models in scientific research comes largely from the perceived limitations of most in vitro studies. Many such studies do not replicate the true environment of most biologic reactions and processes. For example, cell culture techniques, particularly those employing transformed cell lines and primary cultures, are typically unable to reproduce complex cell-cell interactions and result in an alteration of the gene expression profile and growth characteristics of their counterparts within live organisms. An animal model is simply defined as any nonhuman animal with a disease or injury that mimics a similar process found in humans. Used extensively for the evaluation, diagnosis, and treatment of a diverse array of pathologic processes, animal models have been a key component in the development of many medications and treatment protocols. Although large animal models (rabbits, dogs, primates) are sometimes used for drug safety and efficacy studies, the true workhorse of animal models continues to be the rodent. Mice, in particular, have been used extensively due to their small size and rapid growth rates, as well as the ease by which their genomes can be manipulated.

\section{Nongenetic Animal Models of Sinonasal Diseases}

Rodent models of acute and chronic sinonasal diseases have employed several different techniques and have already contributed to our understanding of natural disease course and pathophysiology. Acute rhinosinusitis was first modeled in rabbits 2 decades ago by exposing the maxillary sinus to pathologic bacteria and unilaterally blocking the maxillary sinus ostia. ${ }^{51}$ Since that time, the rabbit model of acute sinusitis has been modified and used by multiple investigators. For example, recently Legert and colleagues ${ }^{52}$ replicated odontogenic maxillary sinusitis by creating a periapical tooth infection with the rabbit's own oral microflora, followed by histopathological evaluation of sinus mucosa and bone. Two primary mouse models of acute rhinosinusitis have been reported in the literature. Bomer and colleagues ${ }^{53}$ developed a model of acute rhinosinusitis by intranasally inoculating mice with Streptococcus pneumoniae. This particular model has since been used by multiple groups and has even been modified to more closely resemble acute fungal rhinosinusitis and chronic rhinosinusitis. ${ }^{54} \mathrm{~A}$ model for acute viral rhinosinusitis was reported by Klemens and colleagues $^{55}$ In this example, mice were nasally inoculated with Sendai virus resulting in an acute viral infection that resolved spontaneously within 10 days.

The complexity inherent in modeling a chronic disease process has resulted in fewer successful models of chronic sinonasal disease. As with the acute disease, the first models of CRS were developed in rabbits. Kumlien and Schiratzki ${ }^{56}$ induced chronic sinonasal inflammation by nasal inoculation with Streptococcus pneumonia and placement of a foreign body in the maxillary sinus. This model has since been used and modified several times, with most recent models being developed instead in mice. Jacob and colleagues 57 were able to induce a persistent, localized bacterial sinusitis in mice either by unilateral maxillary sinus ostium obstruction with merocel nasal packing, or by inoculation with Bacillus fragilis. The use of Steptococcus pneumonia inoculation to model allergic CRS was 
later modified by Wang and colleagues, ${ }^{58}$ who combined bacterial inoculation with unilateral ostiomeatal obstruction with merocel to more accurately model the chronic disease.

The development of a murine model of chronic eosinophilic rhinosinusitis was reported by Bolger's group in 2006. ${ }^{59}$ These mice were sensitized to Aspergillus fumigates extract via intraperitoneal injection and then by repeated nasal challenges, resulting in the creation of a consistent inflammatory response. A similar allergic CRS model was reported by Hussain and colleagues ${ }^{60}$ These mice were sensitized with intraperitoneal injection with ovalbumin followed by repeated intranasal ovalbumin injection over a 12-week period. The bacterial CRS murine systems have thus far been able to successfully model the distinct immunologic characteristics of these closely related diseases. Research into atopic diseases such as asthma and allergic rhinitis has also been aided by mouse models. Classic models have been produced by intraperitoneal injection of a sensitizing agent into mice, which results in the rapid proliferation of $\mathrm{Th} 2$ helper $\mathrm{T}$ cells and allergen-specific IgE. The atopic response can then be modeled by nebulizer or intranasal exposure to allergen.

\section{GENETIC ANIMAL MODELS OF SINONASAL DISEASES:TRANSGENIC/ KNOCK-OUT MICE}

The first transgenic mouse was created in $1982 .{ }^{61}$ Since that time, transgenic mice have become priceless models for studying human diseases and their treatments. A transgenic organism has had a foreign gene deliberately inserted into its genome. The production of a transgenic organism begins with the isolation of a specific gene. There are then 2 methods by which a transgenic organism can be created. In the first, the gene of interest is injected into fertilized embryos, which are subsequently implanted into a pseudopregnant female. A certain percentage of the offspring will be expected to express the gene of interest as heterozygotes. Two heterozygotes can then be mated, which will result in approximately 1 out of 4 offspring being homozygous for the gene of interest. In the second method, embryonic stem cells harvested from the inner cell mass of blastocysts are grown in culture and transformed with the gene of interest. Successfully transformed cells are then reimplanted into a blastocyst and introduced into a pseudopregnant female. Selecting for homozygotes is then performed in the same fashion. Genes can be inserted either randomly or targeted to a particular region in the genome. Endogenous genes can be replaced with nonfunctioning gene sequences to produce a "knock-out" mouse. In some situations "knockin" or "knock-out" of a certain gene is only desired in specific tissues or cell types. Systems now exist by which "target" genes can be activated only in specific cells, and in a temporally controlled manner. Although mice have been the most commonly used transgenic animals, transgenics have now also been created in pigs, sheep, chickens, and most recently primates.

The use of transgenic and genetically modified animals in rhinologic research has thus far been limited. In a hybrid experiment investigating the adoptive transfer hypothesis, Kanaizumi and colleagues ${ }^{62}$ generated Th0, Th1, and Th2 cells in DO11.10 transgenic mice, which express an ovalbumin(OVA)-specific $\mathrm{T}$ cell receptor. These immunoresponsive $\mathrm{T}$ cells 
were then transferred into wild-type BALB/c mice. Following nasal OVA challenge only Th2 cells were recruited to the nasal mucosa, supporting an important role for Th2 responses in allergic rhinitis. Recently, Lane and colleagues ${ }^{63}$ have developed a transgenic mouse model for human chronic rhinosinusitis-associated olfactory dysfunction. Termed the inducible olfactory inflammation (IOI) mouse, this model uses a doxycycline-inducible tetregulated activation system to permit spatially and temporally controlled expression of any target gene. By expressing TNF- $a$ within mouse olfactory epithelium they were able to produce histopathologic evidence of local inflammation that could be maintained for a period of months, and which resulted in loss of olfactory function. Many different transgenic animals have been created with the purpose of exploring individual components of immunologic pathways involved in asthma, allergy, and inflammation. Although used sparingly thus far in rhinologic research, the use of transgenic animals may ultimately augment our understanding of a multitude of sinonasal diseases.

\section{THE FUTURE OF RHINOLOGIC BASIC SCIENCE RESEARCH}

Over the past decade, molecular and cellular technical advances have helped to achieve a better understanding of CRS. In the next decade, it is anticipated that more definitive animal models of CRS will be available to further characterize the pathogenesis of the disease state. Also, a more mature understanding of the epigenetic modifications that sustain Th2 dysregulation in CRSwNP will be necessary. In conclusion, scientific advancements in molecular and genomic technology will continue to benefit the rhinologist investigator in achieving a better understanding of CRS, ultimately leading to more effective pharmacologic interventions in the future.

\section{REFERENCES}

1. Anand VK. Epidemiology and economic impact of chronic rhinosinusitis. Ann Otol Rhinol Laryngol Suppl 2004;193:3-5. [PubMed: 15174752]

2. Williams PM. The beginnings of real-time PCR. Clin Chem 2009;55(4):833-4. [PubMed: 19261911]

3. Essentials of real-time PCR. Product insert. Applied Biosystems; 2006.

4. Claeys S, de Belder T, Holtappels G, et al. Human beta-defensins and toll-like receptors in the upper airway. Allergy 2003;58(8):748-53. [PubMed: 12859553]

5. Lane AP, Saatian B, Yu XY, et al. mRNA for genes associated with antigen presentation are expressed by human middle meatal epithelial cells in culture. Laryngoscope 2004;114(10):1827-32. [PubMed: 15454780]

6. Richer SL, Truong-Tran AQ, Conley DB, et al. Epithelial genes in chronic rhinosi-nusitis with and without nasal polyps. Am J Rhinol 2008;22(3):228-34. [PubMed: 18588753]

7. Lane AP, Truong-Tran QA, Myers A, et al. Serum amyloid A, properdin, complement 3, and tolllike receptors are expressed locally in human sinonasal tissue. Am J Rhinol 2006;20(1):117-23. [PubMed: 16539307]

8. Psaltis AJ, Bruhn MA, Ooi EH, et al. Nasal mucosa expression of lactoferrin in patients with chronic rhinosinusitis. Laryngoscope 2007;117(11):2030-5. [PubMed: 17767090]

9. Ramanathan M, Jr, Spannhake EW, Lane AP. Chronic rhinosinusitis with nasal polyps is associated with decreased expression of mucosal interleukin 22 receptor. Laryngoscope 2007;117(10):183943. [PubMed: 17906500] 
10. Nonaka M, Pawankar R, Fukumoto A, et al. Induction of eotaxin production by interleukin-4, interleukin-13 and lipopolysaccharide by nasal fibroblasts. Clin Exp Allergy 2004;34(5):804-11. [PubMed: 15144475]

11. Wang JH, Kwon HJ, Lee BJ, et al. Staphylococcal enterotoxins A and B enhance rhinovirus replication in A549 cells. Am J Rhinol 2007;21(6):670-4. [PubMed: 18201445]

12. Heinecke L, Proud D, Sanders S, et al. Induction of B7-H1 and B7-DC expression on airway epithelial cells by the toll-like receptor 3 agonist double-stranded RNA and human rhinovirus infection: in vivo and in vitro studies. J Allergy Clin Immunol 2008;121(5):1155-60. [PubMed: 18378285]

13. Lalaker A, Nkrumah L, Lee WK, et al. Chitin stimulates expression of acidic mammalian chitinase and eotaxin-3 by human sinonasal epithelial cells in vitro. Am J Rhinol Allergy 2009;23(1):8-14. [PubMed: 19379605]

14. Kim J, Myers AC, Chen L, et al. Constitutive and inducible expression of b7 family of ligands by human airway epithelial cells. Am J Respir Cell Mol Biol 2005;33(3): 280-9. Epub 2005 Jun 16. [PubMed: 15961727]

15. Saatian B, Yu XY, Lane AP, et al. Expression of genes for B7-H3 and other T cell ligands by nasal epithelial cells during differentiation and activation. Am J Physiol Lung Cell Mol Physiol 2004;287(1):L217-25. [PubMed: 15047568]

16. Brown M, Wittwer C. Flow cytometry: principles and clinical applications in hematology. Clin Chem 2000;46(8 Pt 2):1221-9. [PubMed: 10926916]

17. Bernstein JM, Ballow M, Rich G, et al. Lymphocyte subpopulations and cytokines in nasal polyps: is there a local immune system in the nasal polyp? Otolaryngol Head Neck Surg 2004;130(5):52635. [PubMed: 15138416]

18. Conley DB, Tripathi A, Seiberling KA, et al. Superantigens and chronic rhinosinusitis: skewing of T-cell receptor $\mathrm{V}$ beta-distributions in polyp-derived CD4+ and CD8+ T cells. Am J Rhinol 2006;20(5):534-9. [PubMed: 17063750]

19. Ramanathan M, Jr, Lee WK, Dubin MG, et al. Sinonasal epithelial cell expression of toll-like receptor 9 is decreased in chronic rhinosinusitis with polyps. Am J Rhinol 2007;21(1):110-6. [PubMed: 17283572]

20. Messerklinger W Direction of ciliary flow on the mucosa of the upper respiratory tract. Z Laryngol Rhinol Otol 1951;30:302-8. [PubMed: 14877234]

21. Sanderson MJ, Dirksen ER. Mechanosensitivity of cultured ciliated cells from the mammalian respiratory tract: implications for the regulation of mucociliary transport. Proc Natl Acad Sci U S A 1986;83:7302-6. [PubMed: 3463968]

22. Sanderson MJ, Dirksen ER. Mechanosensitive and beta-adrenergic control of the ciliary beat frequency of mammalian respiratory tract cells in culture. Am Rev Respir Dis 1989;139:432-40. [PubMed: 2536528]

23. Mwimbi XK, Muimo R, Green MW, et al. Making human nasal cilia beat in the cold: a real time assay for cell signalling. Cell Signal 2003;15:395-402. [PubMed: 12618214]

24. Majima Y, Sakakura Y, Matsubara T, et al. Possible mechanisms of reduction of nasal mucociliary clearance in chronic sinusitis. Clin Otolaryngol 1986;11: 55-60. [PubMed: 3486729]

25. Sanderson MJ. High-speed digital microscopy. Methods 2000;21:325-34. [PubMed: 10964577]

26. Sisson JH, Stoner JA, Ammons BA, et al. All-digital image capture and whole-field analysis of ciliary beat frequency. J Microsc 2003;211(Pt 2):103-11. [PubMed: 12887704]

27. Dimova S, Maes F, Brewster ME, et al. High-speed digital imaging method for ciliary beat frequency measurement. J Pharm Pharmacol 2005;57(4):521-6. [PubMed: 15831215]

28. Schipor I, Palmer JN, Cohen AS, et al. Quantification of ciliary beat frequency in sinonasal epithelial cells using differential interference contrast microscopy and high-speed digital video imaging. Am J Rhinol 2006;20(1):124-7. [PubMed: 16539308]

29. Chen B, Shaari J, Claire SE, et al. Altered sinonasal ciliary dynamics in chronic rhinosinusitis. Am J Rhinol 2006;20(3):325-9. [PubMed: 16871938]

30. Erickson VR, Antunes M, Chen B, et al. The effects of retinoic acid on ciliary function of regenerated sinus mucosa. Am J Rhinol 2008;22(3):334-6. [PubMed: 18588770] 
31. Mein CA, Barratt BJ, Dunn MG, et al. Evaluation of single nucleotide polymorphism typing with invader on PCR amplicons and its automation. Genome Res 2000;10(3):330-43. [PubMed: 10720574]

32. Ohnishi Y, Tanaka T, Ozaki K, et al. A high-throughput SNP typing system for genome-wide association studies. J Hum Genet 2001;46(8):471-7. [PubMed: 11501945]

33. Tewfik MA, Bossé Y, Hudson TJ, et al. Assessment of toll-like receptor 2 gene polymorphisms in severe chronic rhinosinusitis. J Otolaryngol Head Neck Surg 2008;37(4):552-8. [PubMed: 19128592]

34. Wang LF, Chien CY, Kuo WR, et al. Matrix metalloproteinase-2 gene polymorphisms in nasal polyps. Arch Otolaryngol Head Neck Surg 2008;134(8):852-6. [PubMed: 18711060]

35. Al-Shemari H, Bossé Y, Hudson TJ, et al. Influence of leukotriene gene polymorphisms on chronic rhinosinusitis. BMC Med Genet 2008;9:21. [PubMed: 18366797]

36. Bernstein JM, Anon JB, Rontal M, et al. Genetic polymorphisms in chronic hyperplastic sinusitis with nasal polyposis. Laryngoscope 2009;119(7):1258-64. [PubMed: 19405090]

37. de Alarcón A, Steinke JW, Caughey R, et al. Expression of leukotriene C4 synthase and plasminogen activator inhibitor 1 gene promoter polymorphisms in sinusitis. Am J Rhinol 2006;20(5):545-9. [PubMed: 17063752]

38. Cheng YK, Lin CD, Chang WC, et al. Increased prevalence of interleukin-1 receptor antagonist gene polymorphism in patients with chronic rhinosinusitis. Arch Otolaryngol Head Neck Surg 2006;132(3):285-90. [PubMed: 16549749]

39. Takeuchi K, Majima Y, Sakakura Y. Tumor necrosis factor gene polymorphism in chronic sinusitis. Laryngoscope 2000;110(10 Pt 1):1711-4. [PubMed: 11037831]

40. Castano R, Bosse Y, Endam LM, et al. Evidence of association of interleukin-1 receptor-like 1 gene polymorphisms with chronic rhinosinusitis. Am J Rhinol Allergy 2009;23(4):377-84. [PubMed: 19671251]

41. Cormier C, Bosse Y, Tewfik M, et al. Polymorphisms in TLR9 gene influence response to corticosteroids in severe chronic rhinosinusitis [abstract]. J Allergy Clin Immunol 2008;121(2 Suppl 1):S218.

42. Endam L, Bossé Y, Filali-Mouhim A. Polymorphisms in the interleukin-22 receptor alpha-1 gene are associated with severe chronic rhinosinusitis [abstract]. AAO Meeting Chicago (IL), September 16-19, 2008.

43. Li X, Quigg RJ, Zhou J, et al. Clinical utility of microarrays: current status, existing challenges and future outlook. Curr Genomics 2008;9(7):466-74. [PubMed: 19506735]

44. Dufva M Introduction to microarray technology. Methods Mol Biol 2009;529:1-22. [PubMed: 19381982]

45. Anand VK, Kacker A, Orjuela AF, et al. Inflammatory pathway gene expression in chronic rhinosinusitis. Am J Rhinol 2006;20(4):471-6.

46. Payne SC, Han JK, Huyett P, et al. Microarray analysis of distinct gene transcription profiles in non-eosinophilic chronic sinusitis with nasal polyps. Am J Rhinol 2008;22(6):568-81. [PubMed: 19178793]

47. Stankovic KM, Goldsztein H, Reh DD, et al. Gene expression profiling of nasal polyps associated with chronic sinusitis and aspirin-sensitive asthma. Laryngoscope 2008;118(5):881-9. [PubMed: 18391768]

48. Rho HS, Lee SH, Lee HM, et al. Overexpression of hepatocyte growth factor and its receptor cMet in nasal polyps. Arch Otolaryngol Head Neck Surg 2006; 132(9):985-9. [PubMed: 16982975]

49. Orlandi RR, Thibeault SL, Ferguson BJ. Microarray analysis of allergic fungal sinusitis and eosinophilic mucin rhinosinusitis. Otolaryngol Head Neck Surg 2007;136(5):707-13. [PubMed: 17478202]

50. Sekigawa T, Tajima A, Hasegawa T, et al. Gene-expression profiles in human nasal polyp tissues and identification of genetic susceptibility in aspirin-intolerant asthma. Clin Exp Allergy 2009;39(7):972-81. [PubMed: 19489917]

51. Drettner B, Johansson P, Kumlien J. Experimental acute sinusitis in rabbit. A study of mucosal blood flow. Acta Otolaryngol 1987;103(5-6):432-4. [PubMed: 3618170] 
52. Legert KG, Melén I, Heimdahl A, et al. Development and characterization of an animal model of dental sinusitis. Acta Otolaryngol 2005;125(11):1195-202. [PubMed: 16353399]

53. Bomer K, Brichta A, Baroody F, et al. A mouse model of acute bacterial sinusitis. Arch Otolaryngol Head Neck Surg 1998;124(11):1227-32. [PubMed: 9821924]

54. Rodriguez TE, Falkowski NR, Harkema JR, et al. Role of neutrophils in preventing and resolving acute fungal sinusitis. Infect Immun 2007;75(12):5663-8. [PubMed: 17875637]

55. Klemens JJ, Thompson K, Langerman A, et al. Persistent inflammation and hyperresponsiveness following viral rhinosinusitis. Laryngoscope 2006;116(7):1236-40. [PubMed: 16826067]

56. Kumblien J, Schiratzki H. Blood flow in the rabbit sinus mucosa during experimentally induced chronic sinusitis. Measurement with a diffusible and with a non-diffusible tracer. Acta Otolaryngol 1985;99(5-6):630-6. [PubMed: 4024914]

57. Jacob A, Faddis BT, Chole RA. Chronic bacterial rhinosinusitis: description of a mouse model. Arch Otolaryngol Head Neck Surg 2001;127(6):657-64. [PubMed: 11405864]

58. Wang H, Lu X, Cao PP, et al. Histological and immunological observations of bacterial and allergic chronic rhinosinusitis in the mouse. Am J Rhinol 2008;22(4):343-8. [PubMed: 18702895]

59. Lindsay R, Slaughter T, Britton-Webb J, et al. Development of a murine model of chronic rhinosinusitis. Otolaryngol Head Neck Surg 2006;134(5):724-30. [PubMed: 16647523]

60. Hussain I, Randolph D, Brody SL, et al. Induction, distribution and modulation of upper airway allergic inflammation in mice. Clin Exp Allergy 2001;31(7):1048-59. [PubMed: 11467996]

61. Palmiter RD, Brinster RL, Hammer RE, et al. Dramatic growth of mice that develop from eggs microinjected with metallothionein-growth hormone fusion genes. Nature 1982;300(5893):611-5. [PubMed: 6958982]

62. Kanaizumi E, Shirasaki H, Sato J, et al. Establishment of animal model of antigen-specific T lymphocyte recruitment into nasal mucosa. Scand J Immunol 2002; 56(4):376-82. [PubMed: 12234258]

63. Lane AP, Turner JH, May L. Reversible loss of neuronal marker protein expression in a transgenic mouse model for sinusitis-associated olfactory dysfunction [abstract]. American Rhinologic Society Meeting-COSM Orlando (FL), May 1-2, 2008. 

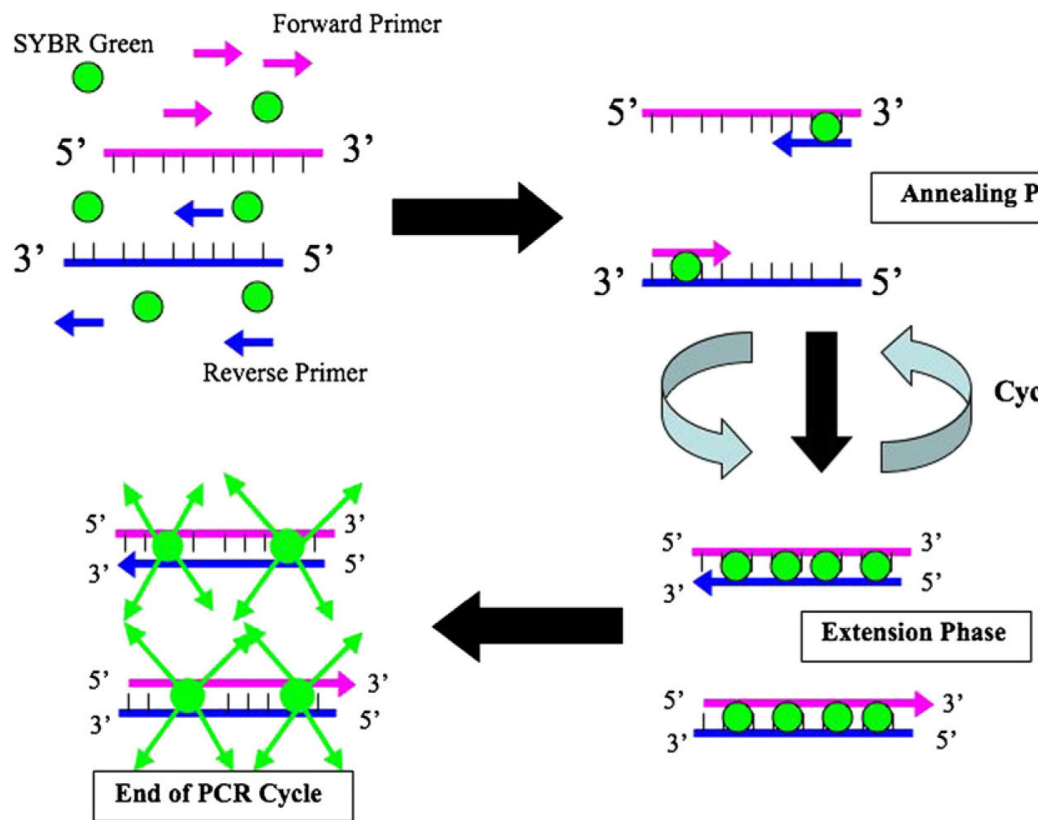

Fig. 1.

Real-time PCR using SYBR Green technology. SYBR Green binds to all dsDNA. As primers attach to the denatured strands of DNA, SYBR Green attaches. With continued cycling and extension each newly formed dsDNA will fluoresce, allowing for quantification. 

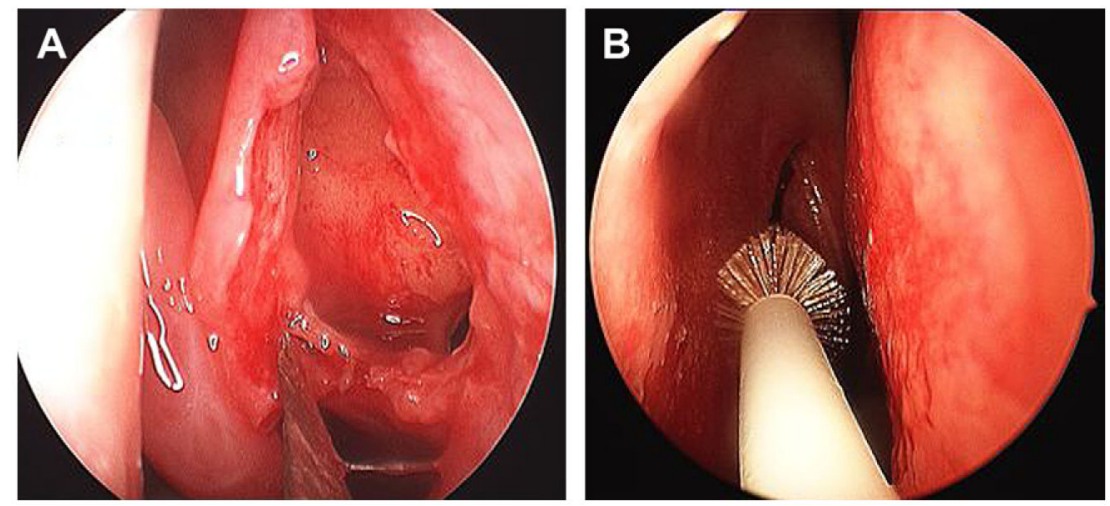

Fig. 2.

A tissue collection for cell culture. (A) Endoscopic view of a resected uncinate process for isolation of SNECs. Virtually any mucosal tissue removed during endoscopic sinus surgery can be used. (B) Endoscopic brushing of epithelial cells in an awake patient in clinic with topical anesthesia. 


\section{Growth of Human Sinonasal Epithelial Cells (HSNEC) in Transwell Culture}
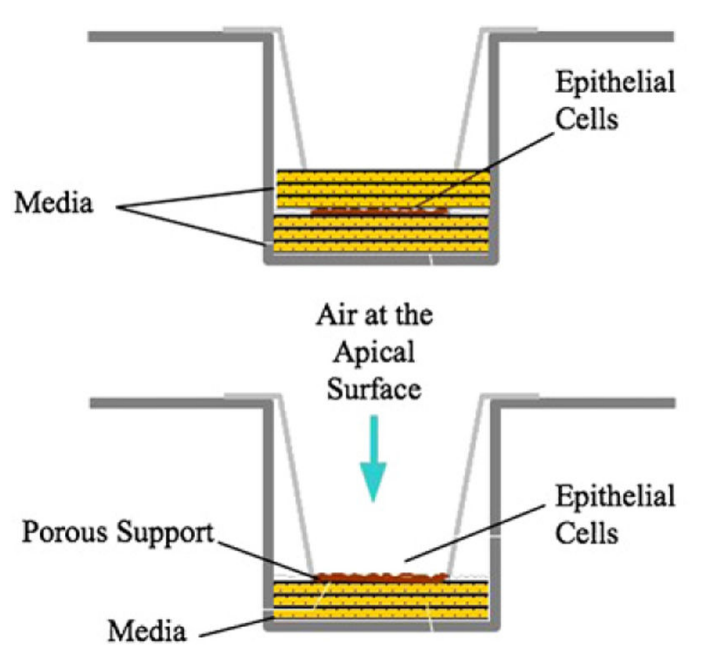

\author{
Submerged cells
}

Ciliated

Cells at the

Air:Liquid

Interface

Fig. 3.

Growth of SNECs in transwell plates. Initially, cells are plated onto a transwell insert with epithelial growth medium above and below the insert (submerged cells). When these cells reach confluence, the medium above the cells is aspirated. Cells are maintained in this manner until they ciliate, mimicking the natural microenvironment of the nose (air/liquid interface). 


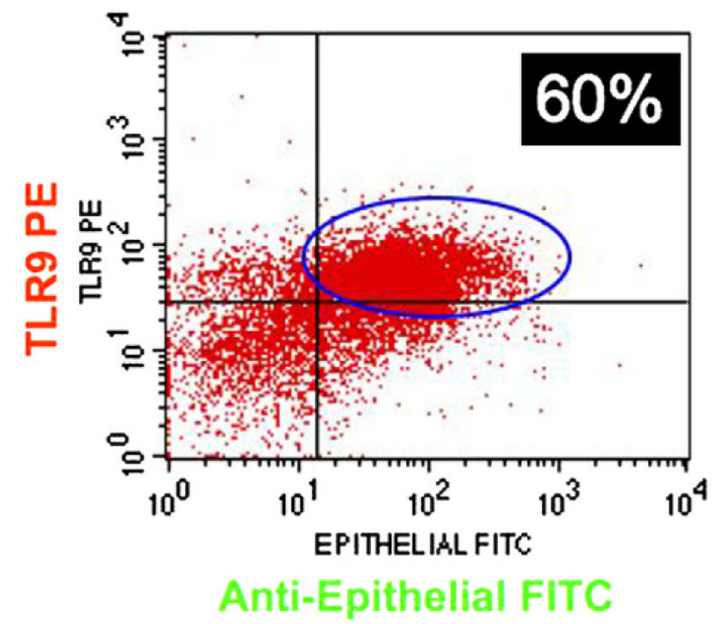

Quadrant Statistics

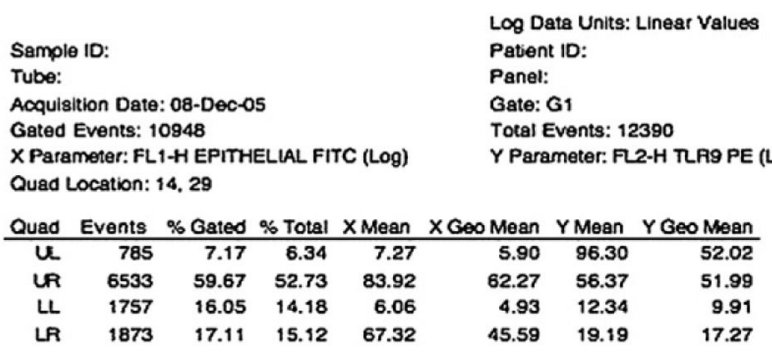

Fig. 4.

Example of data acquired through flow cytometry. This sample is a nasal brushing, which contains epithelial cells and other monocytic cells, that was stained for TLR9 PE and antiepithelial cell marker FITC. The upper right corner depicts all cells in this brushing that were positive for both markers $(60 \%)$. 


\section{Table 1}

Single-nucleotide polymorphisms and CRS

\begin{tabular}{|c|c|c|c|}
\hline Study & Patients & Controls & Findings \\
\hline Bernstein et al, 2009 (USA) & 179 CRSwNP & 153 controls & 2-fold association with TNF-alpha 308 \\
\hline Castano et al, 2009 (Canada) & $206 \mathrm{CRS}$ & 196 controls & $\begin{array}{l}\text { CRS associated strongly with } 5 \text { SNPs of interlekuin-1 receptor- } \\
\text { like } 1 \text { gene }\end{array}$ \\
\hline Endam et al, 2009 (Canada) & $206 \mathrm{CRS}$ & 196 controls & $\begin{array}{l}3 \text { SNPs of interleukin } 22 \text { receptor (IL22RA-1) associated with } \\
\text { CRS }\end{array}$ \\
\hline Cormier et al, 2008 (Canada) & $206 \mathrm{CRS}$ & 196 controls & $\begin{array}{l}\text { No differences in disease with Toll-like receptor } 9 \text { (TLR9), but } 3 \\
\text { SNPs of TLR9 associated with steroid responsiveness in CRS }\end{array}$ \\
\hline De Alarcon et al, 2006 (USA) & $\begin{array}{l}51 \text { chronic eosinophilic } \\
\text { sinusitis (CHES) } 22 \text { ASA } \\
16 \text { chronic inflammatory } \\
\text { sinusitis }\end{array}$ & 66 controls & $\begin{array}{l}\text { Increased prevalence of A->C base exchange in leukotriene C4 } \\
\text { synthase (LTC4S) in CHES }\end{array}$ \\
\hline Cheng et al, 2006 (Taiwan) & 61 CRSwNP 27 CRS & 103 controls & $\begin{array}{l}\text { 3.39-fold association of CRSwNP and } 4.75 \text {-fold association of } \\
\text { CRS with interlenukin-1 receptor antagonist }\end{array}$ \\
\hline Takeuchi et al, 2000 (Japan) & $38 \mathrm{CRS}$ & 38 controls & $74 \%$ of CRS patients had tumor necrosis factor $\mathrm{B} * 2$ allele \\
\hline
\end{tabular}




\section{Table 2}

Gene chip microarray studies in CRS

\begin{tabular}{|c|c|c|c|c|}
\hline Study & Array & Patients/Disease & & Genes \\
\hline $\begin{array}{l}\text { Orlandi et al, } 2007 . \\
\text { Otolaryngol Head Neck } \\
\text { Surg }\end{array}$ & $\begin{array}{l}\text { Glass based array } 6912 \\
\text { genes }\end{array}$ & 4 allergic fungal sinusitis & $\begin{array}{l}3 \text { eosinophilic } \\
\text { mucin rhinosinusitis }\end{array}$ & $\begin{array}{l}\uparrow \text { AFS: cathepsin-B, } \\
\text { sialyltransferase } 1, \text { GM2 } \\
\text { ganglioside protein, S100 }\end{array}$ \\
\hline $\begin{array}{l}\text { Payne et al, 2008. Am J } \\
\text { Rhinol }\end{array}$ & $\begin{array}{l}\text { U133 plus } 2.038,500 \\
\text { genes }\end{array}$ & 2 noneosinophilic CRSwNP & 2 controls & $\begin{array}{l}\uparrow \text { IL-6, IL-8, MCP-1, } \\
\text { hypoxia induced } \\
\text { inflammation, tenascin }\end{array}$ \\
\hline $\begin{array}{l}\text { Sekigawa et al, } 2009 . \\
\text { Clin Exp Allergy }\end{array}$ & $\begin{array}{l}\text { Agilent 1a (v2) 17,000 } \\
\text { genes }\end{array}$ & 9 aspirin intolerant asthma c NP & $\begin{array}{l}5 \text { eisinophilic } \\
\text { Rhinosinusitis with } \\
\text { NP }\end{array}$ & $\uparrow \mathrm{IL} 1 \mathrm{R} 2, \mathrm{INDO}$ \\
\hline $\begin{array}{l}\text { Stankovic et al, } 2008 . \\
\text { Laryngoscope }\end{array}$ & $\begin{array}{l}\text { U133 plus } 2.038,500 \\
\text { genes }\end{array}$ & 10 CRSwNP 10 ASA triad & 10 controls & $\begin{array}{l}\uparrow \text { c-Met PPPR } 1 \downarrow \\
\text { AZGP1PIP }\end{array}$ \\
\hline $\begin{array}{l}\text { Anand et al, 2006. Am J } \\
\text { Rhinol }\end{array}$ & U133A 22,000 genes & 14 chronic hyperplastic sinusitis & 4 control patients & $\begin{array}{l}\uparrow \text { IL-6, IL12-A, IL-13, } \\
\text { TNF-alpha }\end{array}$ \\
\hline
\end{tabular}

